\title{
Thermal Performance Prediction of Indoor Swimming Pool Solar Heating System Using Different Types of Flat-Plate Solar Collectors
}

\author{
Laith Mohammad haddy ${ }^{1}$ Abdul-Salam D. M. Hassen ${ }^{2 *}$ \\ ${ }^{1}$ Department of Mechanical engineering, University of Wasit, Wasit, Iraq, laithhaddy@uowasit.edu.iq. \\ ${ }^{2}$ Department of Mechanical engineering, University of Wasit, Wasit, Iraq, abddawood@uowasit.edu.iq. \\ *Corresponding author: Laith Mohammad haddy,Email :laithhaddy@uowasit.edu.iq \\ Published online: 30 June 2021.
}

Abstract - The current study includes a theoretical study of the enfluence of different types of flat-plate solar collector on the solar fraction factor $(f)$ of a proposed solar heating system used for heating "alShaab Olympic Indoor Swimming Pool" located in Baghdad (Iraq) at a latitude of $33.32^{\circ} \mathrm{N}$. The swimming pool building has external dimensions of $95 \mathrm{~m}$ length, $51 \mathrm{~m}$ width, and $16.5 \mathrm{~m}$ height, it contains two pools, the first is for swimming with dimensions of $(50 \mathrm{~m} * 21 \mathrm{~m})$ with fixed depth of $1.8 \mathrm{~m}$, the second is for diving with an irregular surface area of (351) $\mathrm{m} 2$ and with depth of $5 \mathrm{~m}$. The Total thermal losses from the two pools to the pool hall and from the pool hall to the outdoor environment were calculated for four months of winter season (November, December, January and February) and a computer program was built using the MATLAB (R2008a) environment to solve the mathematical model equations in order to calculate the solar fraction facor $(f)$ of the proposed solar heating system at different solar collecting areas which are $(2000,2500,3000,3500,4000,4500,5000,6000,7000,8000,9000,10000) \mathrm{m} 2$ and at five different types of flat-plate solar collector which are (A: one cover black solar collector, B: one cover selective absorber solar collector, C: two cover black solar collector, D: two cover selective absorber solar collector, and E: pool absorber (PVC) solar collector). The results obtained showed that the highest values of solar fraction factor were obtained when using the solar collector type $\mathrm{D}$, and the lowest values obtained when using the solar collector type E. The values of solar fraction factor $(f)$ of the proposed solar heating system, at solar collecting area of $10000 \mathrm{~m} 2$ and at mass storage of water in the storage tank of 25 $\mathrm{kg} / \mathrm{m} 2$ collecting area, for type D are $84.27 \%$ for November, $72.74 \%$ for December, $69.4 \%$ for January, and $82.91 \%$ for February, and for type E are $56.14 \%$ for November, $41.15 \%$ for December, $37.17 \%$ for January, and $50.6 \%$ for February.

Keywords - Solar heating system, Solar collector area, Solar collector type, Indoor swimming pool, solar fraction factor.

\section{Introduction}

The swimming pools are considered to be an important recreational place all over the world, the inclusion of a building that contains an indoor swimming pool with a heating system for winter use is necessary for the purpose of providing comfortable conditions for users.

It is known that heating of the swimming pool water in addition to the surrounding space costs a lot of energy, so heating these facilities using solar energy heating systems is economically feasible and these systems have been working in many places of the world but in Iraq, there is not yet any Swimming pool is heated using solar energy, most of them are heated using systems that work either with conventional fuel or using electricity. The present study was to deal with this concept .

Kincay et al. [9] designed a model for an Olympic swimming pool with an area of $1800 \mathrm{~m} 2$ to test theoretically on the climatic conditions of four cities in Turkey (Antalya, Adana, Istanbul and Ankara). The results showed that: In Antalya, the percentage of the use of solar energy $64 \%$ and the rate of reduction of the total annual energy $16.2 \%$. In Edna, the percentage of solar energy use was $63.3 \%$ and the percentage of total annual energy reduction was $14.8 \%$. These results are obtained using a collector area of $1600 \mathrm{~m} 2$. In Istanbul, the percentage of the use of solar energy $54.9 \%$ and the rate of reduction of the total annual energy $14.8 \%$. These results are obtained using a collector area of $1800 \mathrm{~m} 2 . \mathrm{In}$

1726-4081 C 2021 The author(s). Published by Association of Arab Universities Journal of Engineering Sciences. This is an open access article under the CC BY-NC license (https://creativecommons.org/licenses/by-nc/4.0/). 
Ankara, the percentage of the use of solar energy 54.3\% and the rate of reduction of the total annual energy $10.8 \%$. These results are obtained using a collector area of $1700 \mathrm{~m} 2$.

Note: the type of solar collector is horizontal, double layer glassed, copper tubing, collector efficiency $=0.85$.

Aboushi and Abu Raed [1] presented an experimental study of the possibility of heating the water of a closed swimming pool, with surface area of $50 \mathrm{~m} 2$ and depth of $1.5 \mathrm{~m}$ at a temperature of $30^{\circ} \mathrm{C}$ placed in a room with floor area of $67 \mathrm{~m} 2$ and a temperature of $24^{\circ} \mathrm{C}$ by using a 150 evacuated tube solar collector, $47 * 1500 \mathrm{~mm}$ each tube. The installed solar system reduces energy consumption about $75 \%$. The payback period for the solar system is less than one year.

Calise et al. [4] studied a proposal to rehabilitate the solar heating system used in the indoor swimming pool of the University of Naples, south of Italy. The volume of the swimming pool is $855 \mathrm{~m} 3$. Performance was studied in terms of energy and economics and simulation of the model using the TRNSYS program. The best performance of energy and economy was achieved using evacuated solar thermal collectors. The simple payback period was about 14 years without incentives.

Dongellini et al. [5] introduced a dynamic model to simulate the solar heating system which consists of horizontal flat solar collectors used to heat an outdoor swimming pool. The model was developed using MATLAB environment to simulate the model using three types of solar collectors: an evacuated collector, a single glazed collector and an unglazed collector applied to three types of swimming pools of different size: paddling pool with dimentions (length $=10 \mathrm{~m}$, width $=4 \mathrm{~m}$ and depth $=0.5 \mathrm{~m}$ ), public swimming pool with dimentions (length $=15 \mathrm{~m}$, width $=6 \mathrm{~m}$ and depth $=1.5 \mathrm{~m}$ ) and third type represents a pool dedicated to competitive sport activities with dimentions (length $=25 \mathrm{~m}$, width $10 \mathrm{~m}$ and depth $=2 \mathrm{~m}$ ). The results of the study showed that unglazed solar collectors are suitable for this types of swimming pool. Evacuation collectors are useful just in case of very large swimming pools in order to reduce the absorbing area of the solar collectors.

Jordaan and Narayanan [7] studied theoretically the possible ways to reduce energy consumption in swimming pool heating. Modeling based on TRNSYS software. The study focused on the aspect of reducing the cost of natural gas through the use of alternative heating methods that use renewable energy. The results showed the following :The evacuated tube collector offers one of the most efficient solar thermal collectors compared to flat panel collectors. In order to maintain the ideal temperature of the swimming pool, solar collectors of all kinds must be at least twice the pool area. The least efficient solar collector option was direct photovoltaic/thermal collectors heating because it needs a very large collector area.

\subsection{System Description}

The site of "AL-SHAAB INDOOR OLYMPIC SWIMMING POOL" in Baghdad was chosen as the location of our study. The geographical location of the site is located in the center of Iraq at (33.32 N 44.23 E). This swimming pool was designed by "FUJITA CORPORATION" and constructed by "MITSUBISHI COMPANY" since the early eighties of the last century for the benefit of the Iraqi Swimming Federation (Iraqi Olympic Committee / Ministry of Youth \& Sport). The swimming pool building has dimensions of $95 \mathrm{~m}$ long, $51 \mathrm{~m}$ width, and $16.5 \mathrm{~m}$ high divided into two sectors. The first sector consists of two floors, the ground floor includes (the management rooms, restaurant, bathrooms, changing rooms and looker's room), separated from the other sector of the building by a tight glass section. The second floor consists of amphitheaters with seats for the audience of more than a thousand spectators. The second sector includes two water basins, the Olympic racing basin with a dimensions of $50 \mathrm{~m} * 21 \mathrm{~m}$ and a fixed depth of about $1.8 \mathrm{~m}$, the second basin (diving pool) with a surface area of $351 \mathrm{~m} 2$ and a fixed depth of about $5 \mathrm{~m}$. Many glass facades are installed on the external walls of the hall building, made of uninsulated single glass without any shading devices. The swimming pool is open to the public every day and it is heated during the winter season by using a diesel-powered heating system. Figures (1) to (4) show the building design maps and photographs of the rig site

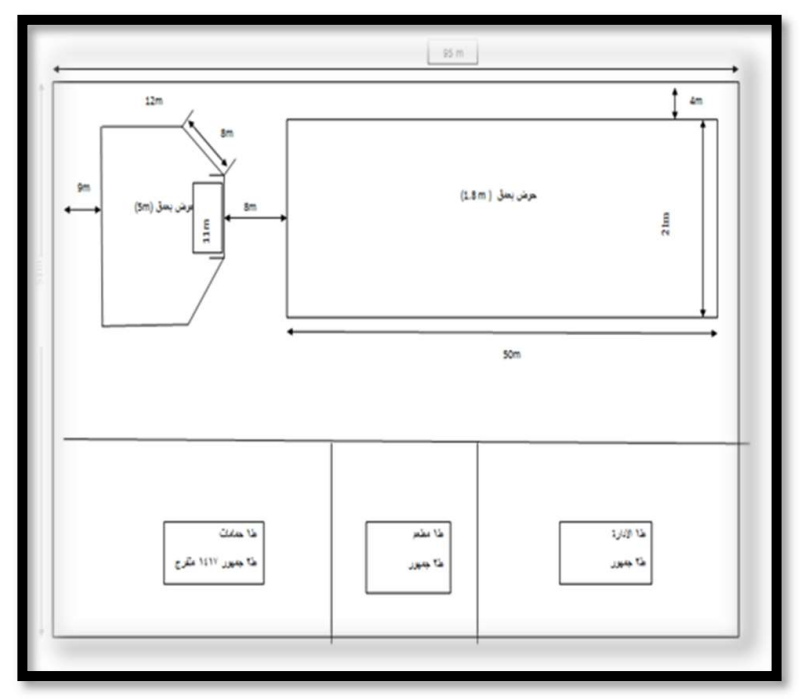

Figure1: Design map for indoor swimming pool by FUJITA CORPORATION 


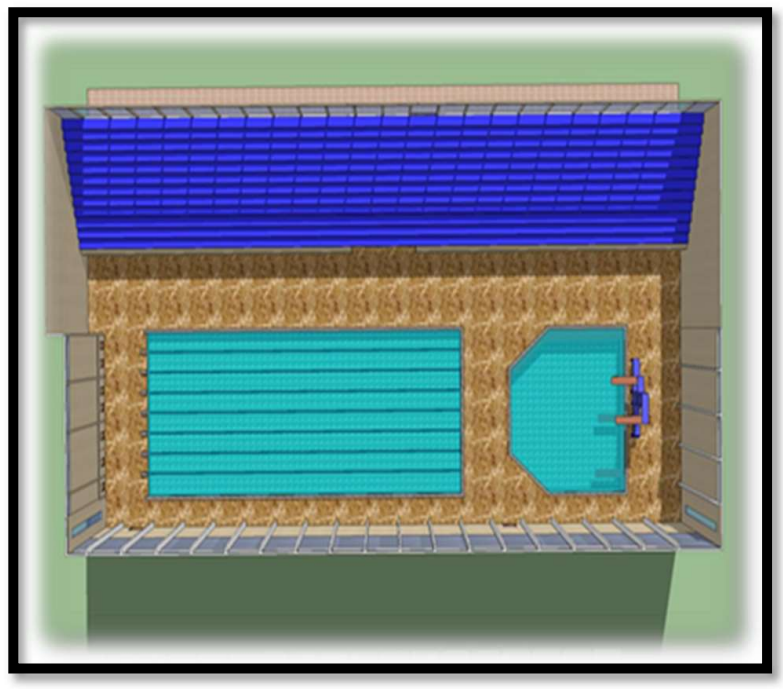

Figure2: Building with indoor swimming pool in three dimensions(top view)

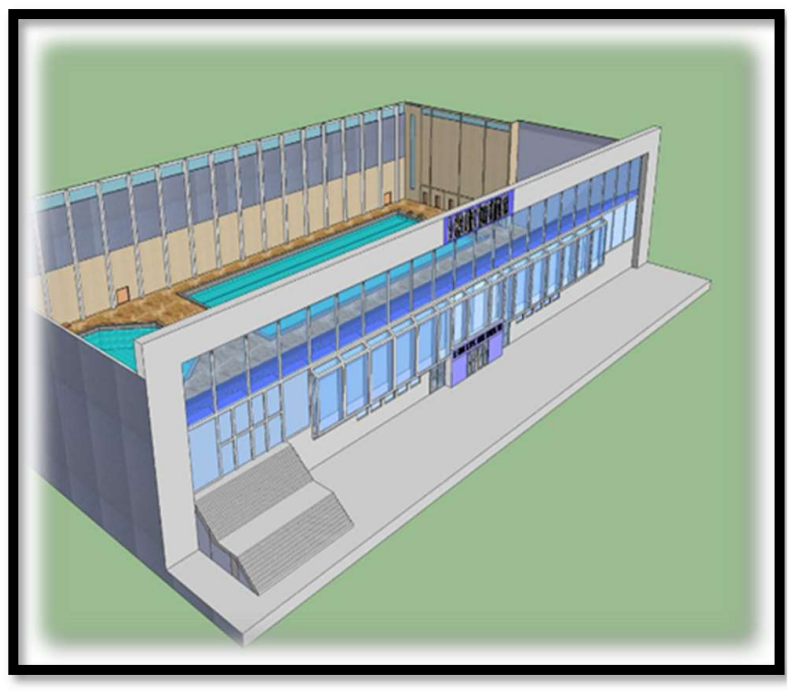

Figure 3: Building with indoor swimming pool in three dimensions (front view)

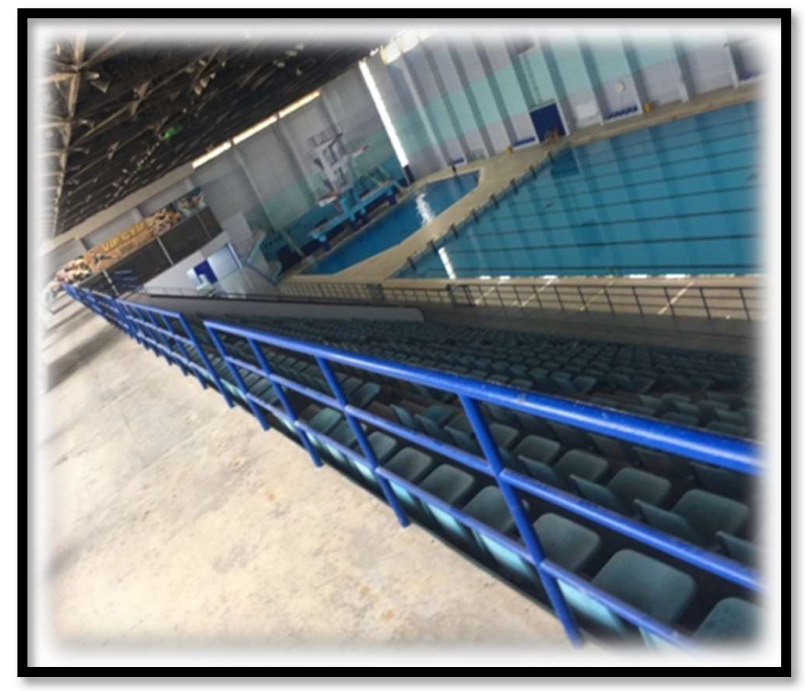

Figure 4: Building with indoor swimming pool

\subsection{Structural Construction of the Building}

The clarification of the materials that made up the walls, ceiling and floor of the swimming pool building is important because they have a significant influence in the calculations of heat losses through them. Table (1) illustrate the structural construction of the building items.

Table 1: Structural construction of building items

\begin{tabular}{|c|c|c|}
\hline Item & structural construction & $\begin{array}{c}\mathrm{U} \\
\left(\mathrm{W} / \mathrm{m}^{2} .{ }^{\circ} \mathrm{C}\right)\end{array}$ \\
\hline wall & $\begin{array}{c}\text { made of a pre-cast concrete } \\
\text { panel with a thickness of } 20 \mathrm{~cm} \text {. }\end{array}$ & 2.757 \\
\hline roof & $\begin{array}{l}\text { consists of an iron structure in } \\
\text { the form of longitudinal and } \\
\text { transverse sections covered with } \\
\text { three layers of sandwich panel } \\
\text { with a thickness of } 5 \mathrm{~cm} \text { per } \\
\text { layer. }\end{array}$ & 0.188 \\
\hline Ground & $\begin{array}{l}\text { consists of three layers which } \\
\text { are: ceramic tiles, mixture of } \\
\text { cement and sand with a } \\
\text { thickness of about } 10 \mathrm{~cm} \text {, } \\
\text { concrete with a thickness of } \\
\text { about } 10 \mathrm{~cm} \text {, and the soil. }\end{array}$ & 2.26 \\
\hline $\begin{array}{l}\text { Wall \& } \\
\text { ground } \\
\text { of the } \\
\text { water } \\
\text { basins }\end{array}$ & $\begin{array}{c}\text { consist of } 20 \mathrm{~cm} \text { thick. pre-cast } \\
\text { concrete panels covered from } \\
\text { the inside with ceramic tiles } \\
\text { specially used in swimming } \\
\text { pools applications. }\end{array}$ & 0.537 \\
\hline
\end{tabular}




\subsection{Operational Method of the Proposed Solar Heating System}

Fig. (5) Shows the schematic diagram for the proposed solar heating system. This system consists of many flatplate panels solar collectors connected to a concrete storage tank used to store hot water during the periods of availability of solar radiation. The working fluid that circulates between the solar storage tank and solar collectors is the pure water. In the proposed solar system there is no heat exchanger in the storage tank separating between the water used in the collecting cycle and the water used in the load cycle. The relatively cold water at the bottom of the storage tank is drawn to pass through the solar collector. The water, after being heated in the solar collector, returns to the storage tank from its upper side. The hot water at the top of the storage tank is drawn and then pumped to a header, which distributes this water to four closed cycles. The hot water in the first cycle is pumped by the pump (P3) to the heating coils in the Air Handling Unit (AHU) for the purpose of heating the air in the swimming pool hall to the required temperature $\left(28^{\circ} \mathrm{C}\right)$. The hot water coming out of the header in the second and third cycles goes through pumps (P4\&P5) to the heat exchangers (HE1\&HE2) respectively. In these exchangers, the heat exchange takes place between the solar-heated water and the water in the two swimming pools (diving basin and Olympic races basin) to convey the water temperature in these basins to the required temperature $\left(26^{\circ} \mathrm{C}\right)$. The hot water in the fourth cycle is drawn from the header to be pumped through the pump (P6) to the heat exchanger HE3. In this heat exchanger, a heat exchange has taken place between the solar-heated water and the water supplied from the local city source, which can then be heated up and brought to the required temperature $\left(60^{\circ} \mathrm{C}\right)$, In the heat exchanger and in the preheat tank, then this water is supplied to the bathroom. the solar-heated water after it performs the heating operations mentioned in the above four cycles returns to the solar storage tank from its lower side. The storage tank is assumed as: a well mixed tank (no thermal stratification exists) and inserted with control system to control the water temperature exiting the tank, also it is filled with water or it is considered as a pressurized tank supplied with a pressure relief valve in case of energy dumping (energy loss through it) does not accure.

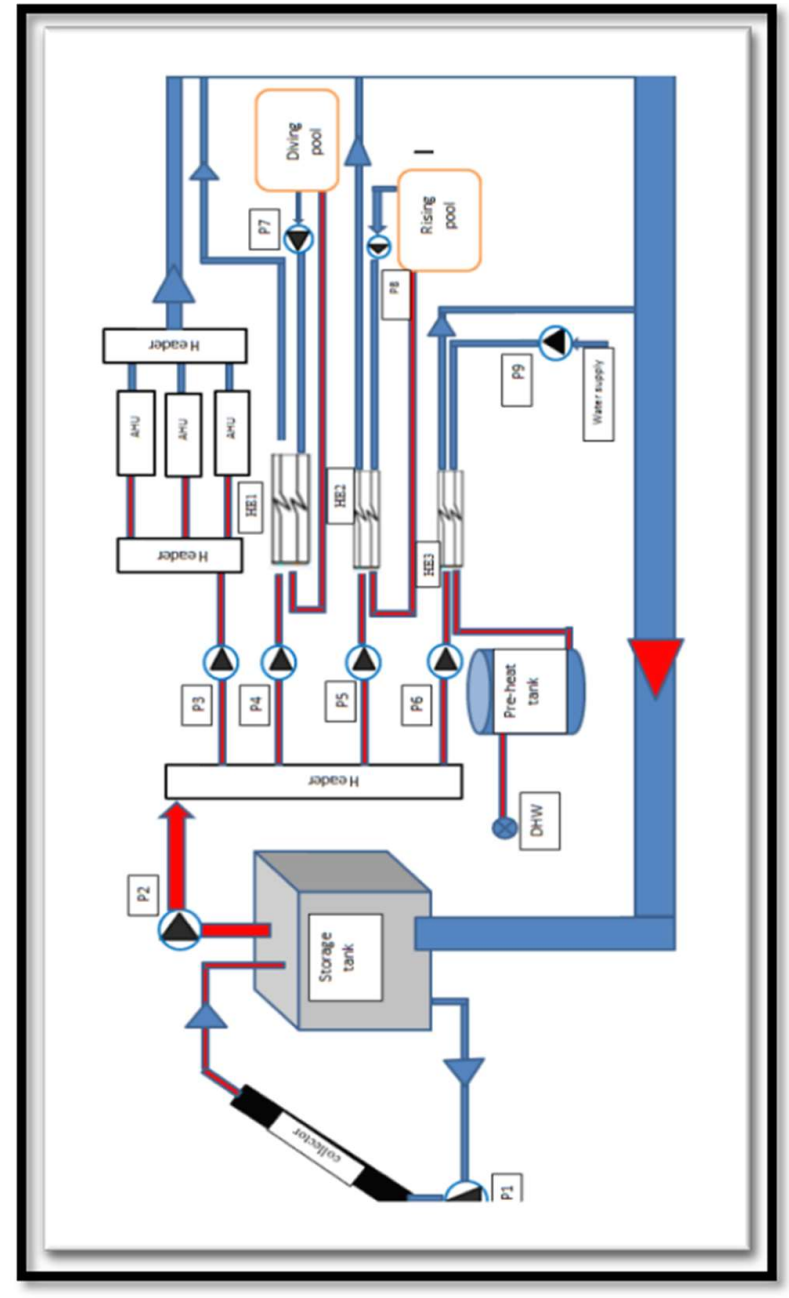

Figure 5: Schematic diagram for proposed solar heating system

\section{Theoretical Analysis and Numerical Simulation}

In the current study, a mathematical model was presented based on the location (latitude) and the climatic conditions of the city of Baghdad (Iraq) which is located the "Al-Shaab Indoor Olympic Swimming Pool" at a latitude of $33.32{ }^{\circ} \mathrm{N}$. All the thermal losses were calculated from the water basins to the building space and from the building space to the outer ambient for the four winter season months (November, December, January, and February). Table (2) shows the values of heat losses from swimming pool and swimming hall. 
Table 2: Calculated heat losses from swimming pool and swimming hall

\begin{tabular}{|c|c|c|c|c|c|}
\hline \multicolumn{2}{|c|}{$Q_{\text {loss }}$} & $\begin{array}{l}\text { Nov. } \\
\text { (kW) }\end{array}$ & $\begin{array}{l}\text { Dec. } \\
(\mathrm{kW})\end{array}$ & $\begin{array}{c}\text { Jan. } \\
(\mathrm{kW})\end{array}$ & $\begin{array}{l}\text { Feb. } \\
(\mathrm{kW})\end{array}$ \\
\hline \multirow{7}{*}{ 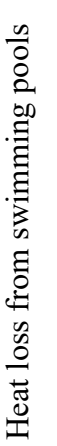 } & $\mathrm{Q}_{\text {cond }}$ & 12.75 & 12.75 & 12.75 & 12.75 \\
\hline & $\mathrm{Q}_{\text {conv }}$ & -8.8 & -8.8 & -8.8 & -8.8 \\
\hline & $\mathrm{Q}_{\mathrm{rad}}$ & 14.00 & 24.555 & 28.23 & 21.5 \\
\hline & $\mathrm{Q}_{\mathrm{fw}}$ & 123.6 & 123.65 & 123.65 & 123.65 \\
\hline & & & & & \\
\hline & $Q_{\text {evap }}$ & $\begin{array}{c}193.3 \\
45\end{array}$ & 193.345 & $\begin{array}{c}193.34 \\
5\end{array}$ & $\begin{array}{c}193.34 \\
5\end{array}$ \\
\hline & $Q_{\text {makeup }}$ & 4.688 & 4.688 & 4.688 & 4.69 \\
\hline \multirow{11}{*}{ 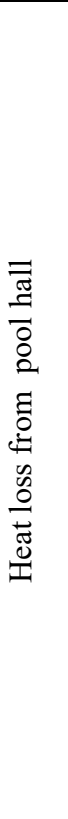 } & $Q_{\text {wall }}$ & 122.3 & 165.88 & 181.23 & 153.52 \\
\hline & $\mathrm{Q}_{\text {glass }}$ & 90.8 & 123.16 & 134.56 & 113.98 \\
\hline & $\mathrm{Q}_{\text {door }}$ & 1.472 & 1.996 & 2.18 & 1.847 \\
\hline & $Q_{\text {roof }}$ & 11.17 & 15.157 & 16.56 & 14.03 \\
\hline & $Q_{\text {ground }}$ & 109.0 & 109.00 & 109.00 & 109.00 \\
\hline & & 0 & & & \\
\hline & $Q_{\text {freshair }}$ & 362.8 & 457.7 & 502.24 & 432.56 \\
\hline & $\mathrm{Q}_{\text {crack }}$ & $2.12 *$ & $2.676^{*}$ & $2.938 *$ & $2.53 *$ \\
\hline & $\mathrm{Q}_{\mathrm{rad}}$ & 14.00 & $24.56^{*}$ & $28.23 *$ & $21.5^{*}$ \\
\hline & $Q_{\text {evap }}$ & $\begin{array}{c}193.3 \\
5^{*}\end{array}$ & $193.35^{*}$ & $\begin{array}{c}193.35 \\
*\end{array}$ & $\begin{array}{c}193.35 \\
*\end{array}$ \\
\hline & $\mathrm{Q}_{\text {conv }}$ & 8.8 & 8.8 & 8.8 & 8.8 \\
\hline 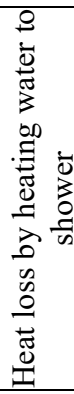 & $\mathrm{Q}_{\mathrm{dhw}}$ & 27.9 & 27.9 & 27.9 & 27.9 \\
\hline \multicolumn{2}{|c|}{$\begin{array}{c}\text { Total heat } \\
\text { losses }\end{array}$} & $\begin{array}{c}873.2 \\
36\end{array}$ & 1048.002 & $\begin{array}{c}1120.6 \\
27\end{array}$ & $\begin{array}{c}1000.1 \\
96\end{array}$ \\
\hline
\end{tabular}

After that, a solar heating system was proposed for the purpose of interviewing these thermal loads, and the percentage of the solar energy contribution was tested in a thermal load interview. The calculations and simulations were performed using the Matlab environment, depending on the general design method for closed-loop solar energy system $((\phi)-,\bar{f}$-chart design method) [10].

\subsection{Critical Radiation Level $(\mathrm{Ht}, \mathrm{c})$}

Is the minimum radiation level required to maintain the collector plate at the temperature of that of the inlet collector fluid. The minimum radiation level, also called the critical radiation level, and can be calculated by the formula [6]:

$$
H_{t, c}=\frac{F_{R} U_{L}\left(T_{i}-\overline{T_{a}}\right)}{F_{R}(\overline{\tau \alpha})}
$$

The minimum critical radiation level $\left(\mathbf{H}_{\mathbf{t}, \mathbf{c}} \min \right)$, can be found on based of $\mathbf{T}_{\min }$ [10]:

$\mathbf{H}_{t, \mathbf{c} \min }=\frac{F_{\mathrm{R}} \mathrm{U}_{\mathrm{L}}\left(\mathrm{T}_{\min }-\overline{\mathrm{T}_{\mathbf{a}}}\right)}{\mathrm{F}_{\mathrm{R}}(\overline{\boldsymbol{\tau} \boldsymbol{\alpha}})}$

Where:

$\mathbf{F}_{\mathbf{R}} \mathbf{U}_{\mathbf{L}}$ : The product of collector heat removal factor $\left(F_{R}\right)$ by collector overall heat-loss coefficient $\left(U_{L}\right) \cdot\left(\mathrm{W} / \mathrm{m}^{2} .{ }^{\circ} \mathrm{C}\right)$

$\boldsymbol{F}_{\boldsymbol{R}}(\overline{\boldsymbol{\tau} \boldsymbol{\alpha}}):$ The product of collector heat removal factor by the monthly average value of transmissivity_absorptivity product of the collector.

$\overline{\boldsymbol{T}_{\boldsymbol{a}}}$ : The monthly average ambient temperature $\left({ }^{\circ} \mathrm{C}\right)$.

$\boldsymbol{T}_{\boldsymbol{m i n}}$ : The minimum useful temperature $\left({ }^{\circ} \mathrm{C}\right)$.

\subsection{The Monthly Average Critical Radiation Ratio $\overline{X_{c}}$}

The ratio of the critical level to the radiation at noon for an average day during the month in which the total radiation for the day is the same as the average for the month. It can be written as follow [6]:

$$
\overline{\mathbf{X}}_{\mathbf{c}, \min }=\frac{\mathbf{H}_{\mathrm{t}, \mathrm{cmin}}}{\mathbf{r}_{\mathbf{n}} \mathbf{R}_{\mathbf{n}} \overline{\mathbf{H}}} * 3600
$$

Substitute eq.(2) in eq.(3) yields:

$$
\overline{\mathbf{X}}_{\mathrm{c}, \min }=\frac{3600}{\mathbf{r}_{\mathbf{n}} \mathbf{R}_{\mathbf{n}} \overline{\mathbf{K}}_{\mathbf{t}} \overline{\mathbf{H}}_{\mathbf{o}}}\left(\frac{\mathbf{F}_{\mathrm{R}} \mathbf{U}_{\mathrm{L}}\left(\mathbf{T}_{\min }-\overline{\mathbf{T}}_{\mathrm{a}}\right)}{\mathbf{F}_{\mathbf{R}}(\overline{\boldsymbol{\tau} \alpha})}\right)
$$




\subsection{Maximum Monthly Average Daily Utilizability $\left(\bar{\phi}_{\max }\right)$}

The fraction of the average daily radiation which could be collected by a solar collector for which ( $\mathbf{F}_{\mathbf{R}}(\overline{\boldsymbol{\tau} \boldsymbol{\alpha}})$ )is unity and the fluid inlet temperature is equal to $T_{\min }$. $\left(\overline{\boldsymbol{\phi}}_{\max }\right)$ will be unity for a perfect collector for which the loss coefficient, $\left(\mathbf{U}_{\mathbf{L}}=\right.$ zero $)$. $\left(\overline{\boldsymbol{\Phi}}_{\max }\right.$ ) will be less than unity for collectors with a non-zero loss coefficient [10].

It has been found by Klien et al. That the value of can be completely specified in term of the monthly clearness index $\left.\overline{(K}_{T}\right)$ and the two other variables, namely the geometry factor $\left(\overline{\boldsymbol{R}} / \boldsymbol{R}_{\boldsymbol{n}}\right)$, and the minimum value of monthly average critical radiation ratio $\left(\overline{\boldsymbol{X}}_{\boldsymbol{c}, \boldsymbol{m i n}}\right)$ by following relation [6]:

$\overline{\boldsymbol{\phi}}_{\max }=\exp \left(\left(\mathbf{a}+\mathbf{b}\left(\frac{\mathbf{R}_{\mathrm{n}}}{\overline{\mathbf{R}}}\right)\right)\left(\overline{\mathbf{X}}_{\mathbf{c}, \text { min }}+\mathbf{c} \overline{\mathbf{X}}_{\mathbf{c}, \text { min }}{ }^{2}\right)\right)$

Where :

$$
\begin{aligned}
& \mathbf{a}=2.943-9.271 \overline{\mathrm{K}}_{\mathrm{T}}+4.03 \overline{\mathrm{K}}_{\mathrm{T}}{ }^{2} \\
& \mathbf{b}=-4.345+8.853 \overline{\mathrm{K}}_{\mathrm{T}}-3.602 \overline{\mathrm{K}}_{\mathrm{T}}{ }^{2} \\
& \mathbf{c}=-0.17-0.3061 \overline{\mathrm{K}}_{\mathrm{T}}+2.936 \overline{\mathrm{K}}_{\mathrm{T}}{ }^{2}
\end{aligned}
$$

\subsection{The Dimensionless Variables(X\&Y)}

$\grave{X}:$ Is a measure of the sensitivity of system performance to the collector fluid inlet temperature [10].

Y: Is the ratio of the energy which would be collected by a solar collector with a specified value of $\left(\boldsymbol{F}_{\boldsymbol{R}}(\overline{\boldsymbol{\tau} \boldsymbol{\alpha}})\right)$ and $\mathrm{U}_{\mathrm{L}}$ equal to zero, to the monthly load [10].

The two dimentionless variables $\grave{X}$ and Y can be found by [6] :

$\grave{X}=\frac{A_{c} F_{R} U_{L}\left(100{ }^{\circ} C\right) N * 24 * 3600}{L_{o}}$

$Y=\frac{A_{c} F_{R}(\overline{\tau \alpha}) N \bar{H}_{t}}{L_{o}}$

\subsection{Fraction factor $(f)$ for solar energy system}

The value of $(f)$ factor can be calculated as [6]:

$$
\begin{aligned}
f= & \bar{\phi}_{\max } . Y-0.015(\exp (3.85 f)-1) * \\
& (1-\exp (-0.15 X)) R_{S}^{0.76}
\end{aligned}
$$

Where $R_{s}$ is the ratio of the standard storage heat capacity per unit of collector area of $350 \mathrm{~kJ} / \mathrm{m}^{2 \circ} \mathrm{C}$ to the actual storage capacity. Although $(f)$ is given implicitly in Eq.(11), it is easy to solve for $(f)$ by Newton's method or by trial and error [6].

\section{Results and Discussions}

In this study, the numerical results obtained from the study are discussed in details. These results include the solar fraction factor $(f)$ values for the proposed solar heating system with five different types of solar thermal collectors used (type A: one cover black solar collector, type B: one cover selective absorber solar collector, type C: two cover black solar collector, type D: two cover selective absorber solar collector, and type E: pool absorber or (PVC) solar collector) and for four months of the winter season (November, December, January, and February). Figure (6) illustrate the values of the ambient temperature $\left(\overline{\boldsymbol{T}}_{\boldsymbol{a}}\right)$, the intensity of the solar irradiation on the horizontal surface $(\overline{\boldsymbol{H}})$, and the intensity of the solar irradiation on the tilt surface of the solar collector $\left(\overline{\boldsymbol{H}}_{\boldsymbol{t}}\right)$ for the city of Baghdad (Iraq) and for four months that represent the months in which the calculations were performed. These values are daily values calculated on a monthly average basis where these values are used with the equations included in the third paragraph to find the values of the solar fraction factor $(f)$ of the proposed solar heating system.

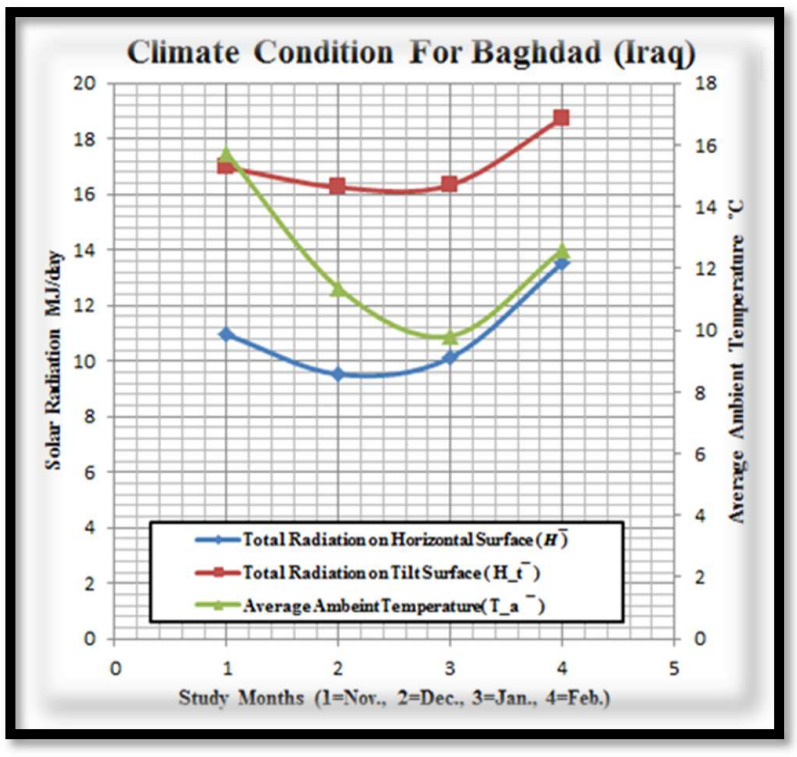

Figure 6: Average climate conditions for the city of Baghdad (Iraq)

The average values for the coefficients $\left(\bar{T}_{a}\right),(\bar{H})$, and $\left(\bar{H}_{t}\right)$ was calculated from the daily values of these parameters according to the readings of the meteorological stations affiliated to the Iraqi Ministry of Agriculture within 5 years. 


\subsection{Effect Of Collector Surface Area (Ac) On Solar Faction Factor (f)}

Figures (7) through (10) show the relation between solar collector area and the solar fraction factor for five types of solar collectors used, for one value of mass of water in solar storage tank $\mathrm{M}_{\mathrm{S}}\left(25 \mathrm{Kg}\right.$ of water $/ \mathrm{m}^{2}$ of collector area), and for four months of the winter season.

Drawing the relationship between the solar collecting area and the solar fraction factor is a very important tool can be placed in the hands of the designer of the solar system through which, and according to the economic criteria, a right decision can be taken with regard to the required size of the system for a specific application. So that the designer can choose between designing a large size solar system with large solar collecting area, and little reliance on the auxiliary system ( that works on conventional fuel) or designing a solar system of a smaller size with greater reliance on the auxiliary system or any other design that meets the economic consideration.

It is noted in all the aforementioned figures, that the solar fraction factor $(f)$ of the solar system increases with the increase of the solar collecting area. This increment is of a decreasing order, this can be seen when looking at figures (7) to (10), until reaching a solar collecting area of $\left(10000 \mathrm{~m}^{2}\right)$ noticed that at the last readings it was at increase every $\left(1000 \mathrm{~m}^{2}\right)$ collection area, lead to an increase in the solar fraction factor equivalent to what was increased when increasing $\left(500 \mathrm{~m}^{2}\right)$ at the beginning of the readings. The results of the study showed that, at large solar collecting area (greater than $6000 \mathrm{~m}^{2}$ ), the increase in solar fraction factor per each $1000 \mathrm{~m}^{2}$ increase in the collecing area will be roughly equivalent to the increase in this factor per each $500 \mathrm{~m}^{2}$ increase in the collecting area at collecting area smaller than $6000 \mathrm{~m}^{2}$. For this reason, it would be appropriate to include all the equation for the curves, which represent the relationship between the solar fraction factor and the collecting area for each type of solar collector and for the four months of winter season ( Nov., Dec.,Jan., and Feb.).

The Governing Equations that Relats the Solar Fraction Factor $(f)$ and the Collecting Area $\left(\mathrm{A}_{\mathrm{c}}\right)$ for Each Type of Solar Collector are given below for each considered month, these are:

\section{November}

type $A: f=3.2+0.01 A_{c}-4.7 * 10^{-7} A_{c}{ }^{2}$

type $B: f=2.26+0.013 A_{c}-5.4 * 10^{-7} A_{c}^{2}$

type $C: f=0.69+0.0135 A_{c}-5.1 * 10^{-7} A_{c}^{2}$

type D: $f=-0.72+0.014 A_{c}-5.7 * 10^{-7} A_{c}{ }^{2}$

type $E: f=6.28+7.9 * 10^{-3} A_{c}-2.95 * 10^{-7} A_{c}^{2}$

\section{December}

type A: $f=1.14+8.93 * 10^{-3} A_{c}-3.1 * 10^{-7} A_{c}{ }^{2}$

type B: $f=0.46+0.01 A_{c}-3.6 * 10^{-7} A_{c}^{2}$

type $C: f=-0.23+9.8 * 10^{-3} A_{c-3.2} * 10^{-7} A_{c}^{2}$

type D: $f=-1.1+0.01 A_{c}-3.5 * 10^{-7} A_{c}^{2}$

type $E: f=2.78+5.7 * 10^{-3} A_{c}-1.9 * 10^{-7} A_{c}^{2}$

January

type $A: f=0.81+8.2 * 10^{-3} A_{c}-2.7 * 10^{-7} A_{c}^{2}$

type B: $f=0.22+9.3 * 10^{-3} A_{c}-3.1 * 10^{-7} A_{c}^{2}$

type $C: f=-0.28+9.04 * 10^{-3} A_{c}-2.7 * 10^{-7} A_{c}^{2}$

type D: $f=-1+0.01 A_{c}-3 * 10^{-7} A_{c}^{2}$

type $E: f=2.09+5.1 * 10^{-3} A_{c}-1.7 * 10^{-7} A_{c}^{2}$

\section{February}

type $A: f=2.19+0.011 A_{c}-4.3 * 10^{-7} A_{c}^{2}$

type B: $f=1.3+0.012 A_{c-5} * 10^{-7} A_{c}^{2}$

type $C: f=0.06+0.012 A_{c}-4.6^{*} 10^{-7} A_{c}^{2}$

type D: $f=-1.2+0.014 A_{c}-5.16 * 10^{-7} A_{c}{ }^{2}$

type $E: f=4.7+7.2 * 10^{-3} A_{c}-2.59 * 10^{-7} A_{c}^{2}$

Comparing the shape of the relationship between the solar fraction factor $(f)$ and the solar collecting area (Ac) shown in figures (7) to (10), a great similarity is observed between what was reached in this study and what was reached by Klein [8] (developed a relation of the seasonal average solar fraction with the collector area for heating systems) and by Qussai [9] (developed a relation of the seasonal average solar fraction with the collector area for cooling systems). As this relationship is not a linear relationship between them.

Referring to the mathematical model, for determining the thermal performance of the solar system and calculating the solar fraction factor for this system, it is noted that the solar collecting area $\left(\mathrm{A}_{\mathrm{c}}\right)$ interferes with the calculation of the parameters $\grave{X}$ and Y (equations (9), and (10)), which intern enters into the calculation of the solar fraction factor of the system $(f)$ (equation 11). Where the increase in value of parameters $\grave{X}$ and $\mathrm{Y}$, lead to an increase in the value of solar fraction factor $(f)$ of the system. 


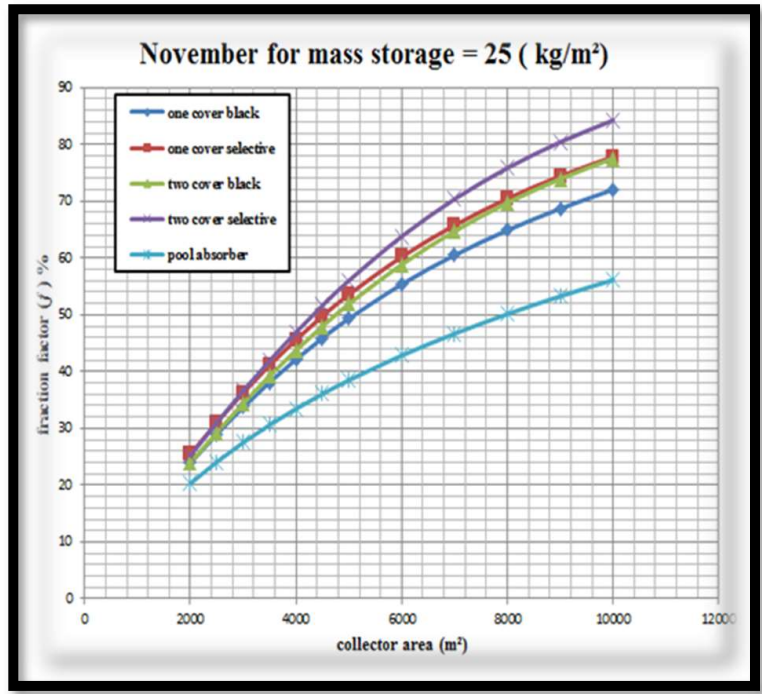

Figure 7 : Effect of collector area on fraction factor for five types of solar thermal, November

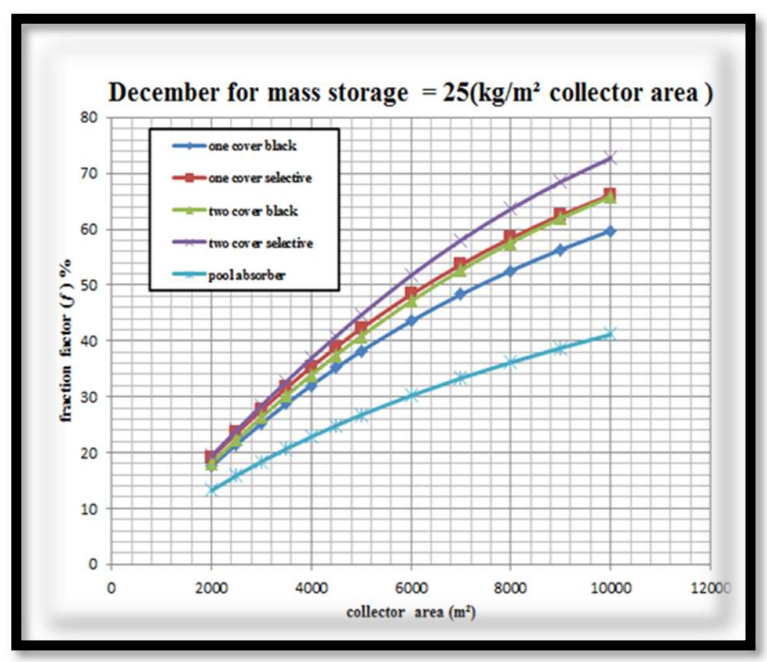

Figure 8: Effect of collector area on fraction factor for five types of solar thermal, December

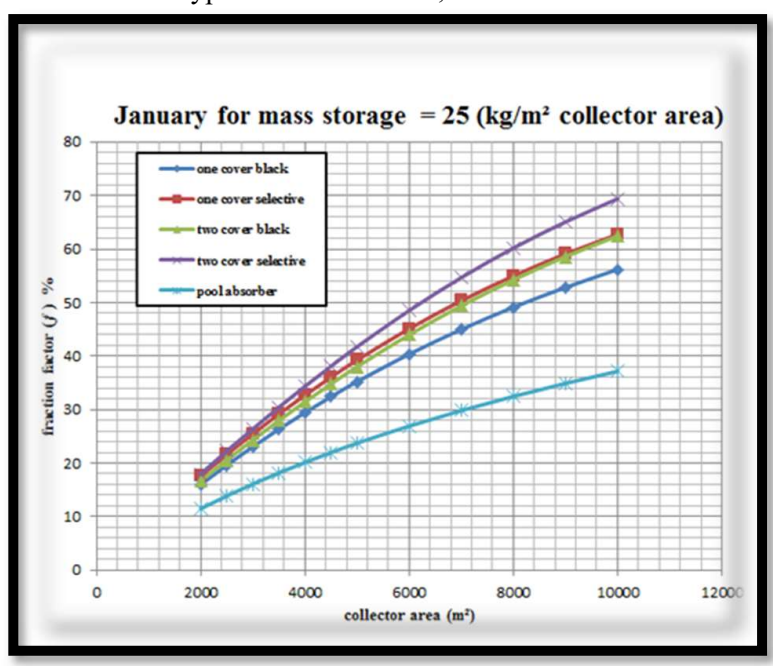

Figure 9: Effect of collector area on fraction factor for five types of solar thermal collector, January

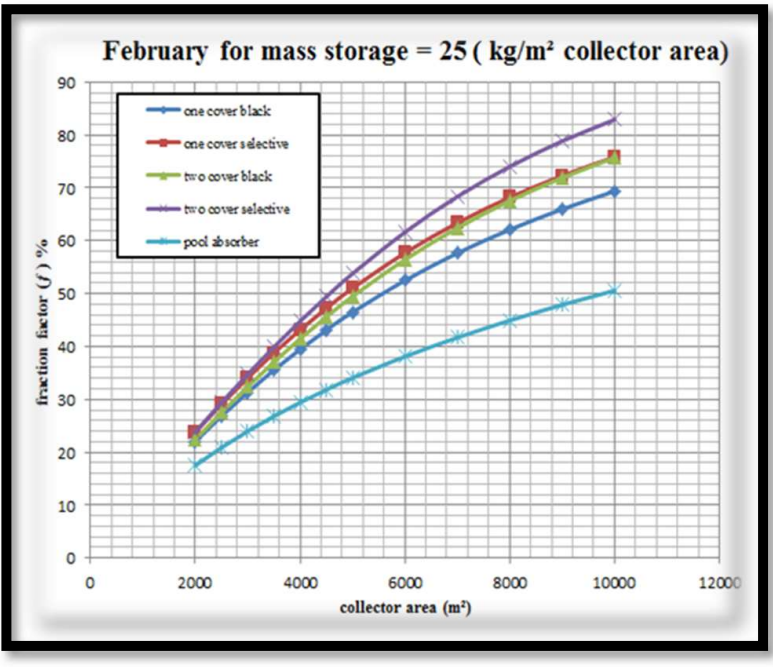

Figure 10 : Effect of collector area on fraction factor for five types of solar thermal collector, February

\subsection{The Effect Of Solar Collector Types On Solar Faction Factor}

Five different types of solar thermal collectors (type A, type B, type C, type D, and type E) are used in the current study .

each type of solar collector used differs from the other type in the values of the coefficients FRUL and FR $(\tau \alpha) n$ where FR is the heat removal factor of the collector, $\tau$ is the transmissivity of the collector transparent cover, and $\alpha$ is the absorptivity of the absorber plate of the collector. The values of the coefficients FRUL and FR $(\tau \alpha) n$ for each solar collector used are shown in the following table.

Table 3 : Values of $F_{R} U_{L}$ and $F_{R}(\tau \alpha) n$ for the solar collector used $[2,11]$

\begin{tabular}{|c|c|c|c|c|c|}
\hline coefficient & \multicolumn{5}{|c|}{ Collector type } \\
\cline { 2 - 6 } & $\begin{array}{c}\text { Type } \\
\mathrm{A}\end{array}$ & $\begin{array}{c}\text { Type } \\
\mathrm{B}\end{array}$ & $\begin{array}{c}\text { Type } \\
\mathrm{C}\end{array}$ & $\begin{array}{c}\text { Type } \\
\mathrm{D}\end{array}$ & $\begin{array}{c}\text { Type } \\
\mathrm{E}\end{array}$ \\
\hline $\mathrm{F}_{\mathrm{R}} \mathrm{U}_{\mathrm{L}}$ & 6.58 & 5.1 & 4.02 & 2.89 & 17.4 \\
\hline $\mathrm{F}_{\mathrm{R}}(\tau \alpha)_{\mathrm{n}}$ & 0.74 & 0.74 & 0.684 & 0.684 & 0.87 \\
\hline
\end{tabular}

Basically, according to the Hotel-Whillier-Bliss equation used to calculate the rate of useful energy gained by flat-plate solar collector [10]

$Q_{u}=A_{c}\left[I_{T} * F_{R}(\tau \alpha)-F_{R} U_{L}\left(T_{i}-T_{a}\right)\right]^{+}$

where:

$\mathrm{Q}_{\mathrm{u}}$ : rate of useful energy gained by a flat-plate solar collector

$\mathrm{A}_{\mathrm{c}}$ : solar collector area. 
$\mathrm{I}_{\mathrm{T}}$ : solar radiation per unit area incident on the collector Surface.

$\mathrm{T}_{\mathrm{i}}$ : collector fluid inlet temperature.

$\mathrm{T}_{\mathrm{a}}:$ ambient temperature.

It is noted from the equation that the value of the rate useful solar energy gained $\left(Q_{u}\right)$ increases with the increase in the value of parameter $F_{R}(\tau \alpha)_{n}$ and with the decrease in the value of the parameter $F_{R} U_{L}$. Therefore, the flat-plate solar collector that has a high value the parameter $F_{R}(\tau \alpha)_{n}$ and a low value the parameter $F_{R} U_{L}$ can be expected, in general, to have a better thermal performance.

The collector parameters $\mathrm{F}_{\mathrm{R}} \mathrm{U}_{\mathrm{L}}$ and $\mathrm{F}_{\mathrm{R}}(\tau \alpha)_{\mathrm{n}}$ can be determined from the standard test of collector efficiency [2].

Through the results obtained from the study, it can be observed in general that the lowest values of the solar fraction factor $(f)$ at a given solar collecting area was obtained when using the solar collector type E (pool absorber (PVC) solar collector). Then, the value of this factor starts to increase in succession (for the same solar collecting area) when using solar collectors type A, then type $\mathrm{C}$, then type $\mathrm{B}$, while the highest value of $(f)$ was obtained when using the solar collector type D (two cover selective absorber solar collector ).

The decrease in the thermal performance of the collector type E, which gave the lowest value to the factor $(f)$ when using in the solar system, is due to the high amount of heat loss from the collector to the ambient as a result of not containing a glass cover above the absorption pipes. Nevertheless, this type of solar collector is highly recommended for use in swimming pool heating application for the following reasons: cheap in price, easy in the structural composition (it does not contain a glass cover and un insulating material), and the absorbent part of the collector is a bundle of black coated (PVC) tubes. As for the solar collector of type $\mathrm{D}$, which gave a high value to the factor $(f)$, it is characterized by a low value of heat loss from the collector to the surrounding (it contains two glass cover), high absorbtance and low emittance of the absorbent plate because this plate is painted with a selective coating (black metal oxides). However, one of the major disadvantage of this kind of collector is the high price. Table (4) shows the values of the solar fraction factor obtained from the study for the five types of solar collector used at a solar collecting area of $10000 \mathrm{~m}^{2}$, at mass of water in solar storage tank $\mathrm{M}_{\mathrm{S}}$ $=25 \mathrm{Kg}$ of water $/ \mathrm{m}^{2}$ of collector area), and at four months of the winter season.
Table 4 : Values of solar fraction factor $(f)$ for different type of solar collector at solar collection area of $10000 \mathrm{~m}^{2}$

\begin{tabular}{|c|c|c|c|c|c|}
\hline \multirow{2}{*}{$\begin{array}{l}\text { 胥 } \\
\sum^{0}\end{array}$} & \multicolumn{5}{|c|}{ Values of $(f)$ at $10000 \mathrm{~m}^{2}$ solar collection area } \\
\hline & $\begin{array}{l}\text { Type } \\
\text { А \% }\end{array}$ & $\begin{array}{c}\text { Type B } \\
\%\end{array}$ & $\begin{array}{c}\text { Type C } \\
\%\end{array}$ & $\begin{array}{c}\text { Type D } \\
\%\end{array}$ & $\begin{array}{l}\text { Type } \\
\text { Е \% }\end{array}$ \\
\hline Nov & 72.03 & 77.85 & 77.56 & 84.27 & 56.14 \\
\hline Dec. & 59.72 & 66.14 & 65.83 & 77.74 & 41.15 \\
\hline Jan. & 56.20 & 62.75 & 62.46 & 69.40 & 37.17 \\
\hline Feb. & 69.38 & 75.85 & 75.72 & 82.91 & 50.60 \\
\hline
\end{tabular}

The effect of the area of solar collector on the solar fraction factor of the proposed system has been tested for five types of solar collector. The results of the study are represented in the form of curves that can be used by the solar system designers when choosing the size of the system components. Such curves save a lot of time and effort in the selection process.

\section{Conclusion}

In this study, a theoretical approach has been made to find out the effect of the type of solar collector at different collector area on the performance of solar heating system proposed to using for heating a closed or an indoor Olympic swimming pool located in the city of Baghdad-Iraq "Al-Shaab Olympic Indoor Swimming Pool". From the results obtained, the following conclusion can be included:

- The highest value of the monthly total heating load calculated for the swimming pool during the four winter months, that were taken into consideration in the study, was for a month of January. The value of this heating load reached $1120.627667 \mathrm{KW}$ at an average outdoor air temperature $\left(\overline{\boldsymbol{T}}_{\boldsymbol{a}}\right)$ equal to $9.82^{\circ} \mathrm{C}$, and an average daily intensity of solar radiation $(\overline{\boldsymbol{H}})$ falling on the horizontal surface equal to 10.13 $\mathrm{MJ} / \mathrm{m}^{2}$.day.

- The increasing in the solar collecting area lead to an increase in the solar fraction factor $(f)$ of the solar system for all types of solar collectors used in the study.

- The highest values of the solar fraction factor are obtained by using the solar collector type D (two cover selective absorber thermal collector)which are at while the lowest values are obtained by using solar collector type E (pool absorber solar thermal collector). See table (4).

- At collecting area of $10000 \mathrm{~m}^{2}$ and at storage mass (mass of water in the storage tank) equal to $25 \mathrm{Kg}$ of water per $\mathrm{m}^{2}$ collecting area, the values of heating system solar fraction factor, when 
using two glass cover selective absorber plate collector (type D) are $84.27 \%$ for November, $72.74 \%$ for December, $69.4 \%$ for January, and $82.91 \%$ for February, and for pool absorber (PVC) solar collector (type E) are $56.14 \%$ for November, $41.15 \%$ for December, $37.17 \%$ for January, and $50.6 \%$ for February.

- Using the mathematical model to calculate the solar fraction factor $(f)$ of the proposed solar heating system (listed in paragraph three) and using a computer program MATLAB environment to solve the equations of this model gave reasonable result of this factor when compared with similar previous research.

\section{References}

[1] Aboushi, A. and Raed, A., 2015. Heating indoor swimming pool using solar energy with evacuated collectors. In Proceedings of the 2015 International Conference on Advances in Environment Research (Vol. 87, pp. 90-94).

[2] ASHRAE standard 93-77, "Methods of Testing to Determine the Thermal Performance of Solar Collector", American society of heating, Refrigerating and Air-Conditioning Engineers, Inc, Atlanta, Ga., 1977.

[3] Beckman, W.A., Klein, S.A. and Duffie, J.A., 1977. Solar heating design, by the f-chart method. NASA STI/Recon Technical Report $A, 78$.

[4] Calise, F., Figaj, R.D. and Vanoli, L., 2018. Energy and economic analysis of energy savings measures in a swimming pool centre by means of dynamic simulations. Energies, 11(9), pp.127.

[5] Dongellini, M., Falcioni, S., Martelli, A. and Morini, G.L., 2015. Dynamic simulation of outdoor swimming pool solar heating. Energy Procedia, 81, pp.1-10.

[6] Duffie, J.A. and Beckman, W.A., 2013. Solar engineering of thermal processes. John Wiley \& Sons.

[7] Jordaan, M. and Narayanan, R., 2019. A numerical study on various heating options applied to swimming pool for energy saving. Energy Procedia, 160, pp.131-138.

[8] Joudi, K.A. and Abdul-Ghafour, Q.J., 2003. Development of design charts for solar cooling systems. Part II: Application of the cooling fchart. Energy Conversion and Management, 44(2), pp.341-355.

[9] Kincay, O., Utlu, Z. and Akbulut, U., 2012. Technical and economic performance analysis of utilization of solar energy in indoor swimming pools, an application. Journal of solar energy engineering, 134(1), PP.0145021-0145028

[10]Klein, S.A. and Beckman, W.A., 1979. A general design method for closed-loop solar energy systems. Solar energy, 22(3), pp.269282.

[11] Seminar on Large-Scale Solar Thermal Systems From February 24th-28th (2014) in Berlin, Germany, Renewables Academy (RENAC) AGI Schonbauser Allee1011110119 Berlin.

\section{Nomenclature}

$\overline{\boldsymbol{H}_{\boldsymbol{o}}}$ : Monthly average daily total insolation on an extraterrestrial horizontal surface (MJ/day)

$\overline{\mathbf{H}_{\mathbf{t}}}$ : Monthly average daily total solar radiation on tilt surface (MJ/day)

$\overline{K_{T}}$ : Monthly mean clearness index

$\mathbf{L}_{\mathbf{o}}$ : Total heat losses from the swimming pool and swimming hall for month (GJ)

N : Number of day in the month (day)

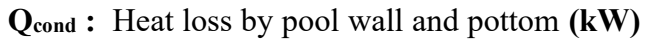

$\mathbf{Q}_{\text {conv }}$ : Heat loss by convection between water surface and air hall $(\mathbf{k W})$

$\mathbf{Q}_{\text {rad }}$ : Heat loss by radiation from water surface to hall $(\mathbf{k W})$

Qfw : Heat loss by fresh water supplied (kW)

$\mathbf{Q}_{\text {evap }}$ : Heat loss by evaporation water from water surface $(\mathbf{k W})$

$\mathbf{Q}_{\text {makeup }}$ : Heat loss by makeup water compensate of water evaporation (kW)

$\mathbf{Q}_{\text {wall }}$ : Heat loss through concrete wall (kW)

Qglass: Heat loss through glass windows (kW)

$\mathbf{Q}_{\text {door : Heat loss through Iron doors }}(\mathbf{k W})$

Qroof : Heat loss through roof (sandwich panel) (kW)

Qground : Heat loss through ground (kW)

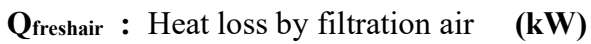

Qcrack : Heat loss through crack of windows and doors (kW)

$\overline{\mathbf{R}}$ : Monthly mean total radiation tilt factor 
$\mathbf{r n}_{\mathbf{n}}$ : Ratio of total radiation at noon to the daily total radiation
$\mathbf{R}_{\mathbf{n}}$ : Ratio of total radiation at noon on the tilted surface to that on a horizontal surface based on a monthly average.

لحمام سباحة داخلي باستخدام أنو اع مخنلفة من

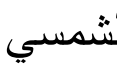

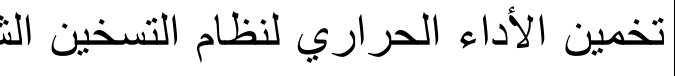
المجمعات الثمسية ذات الألو الح المسطحة النمئ

\section{لبث محمد هادي هاشم1 ,عبد السلام داود محمد2*2}

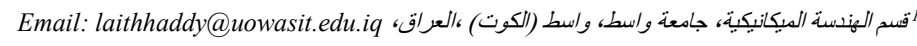

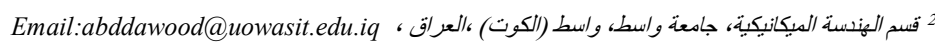

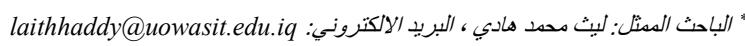

شر في: 30 حزيران 2021

الخلاصة ـ قدمت الدر اسة الحالية دراسة نظرية حول تأثثر أنو اع مختلفة من مجمعات الألو اح الثمسية المسطحة على عامل الكسر الثمسي

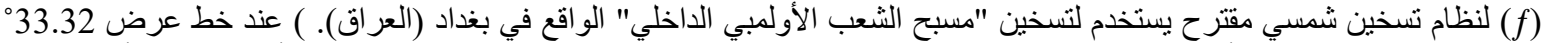

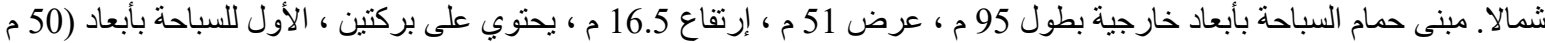

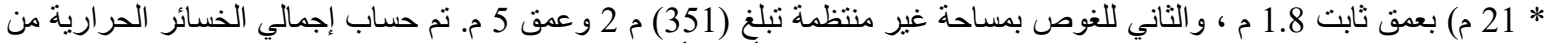

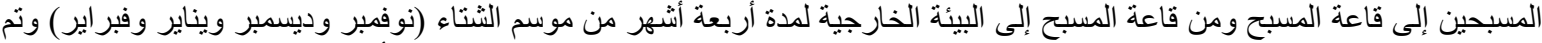

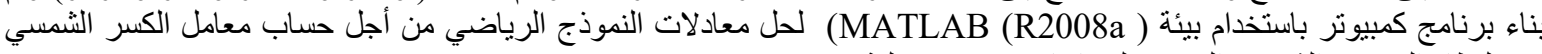

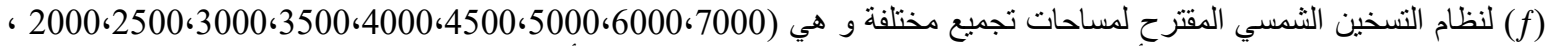

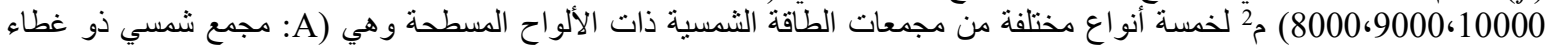

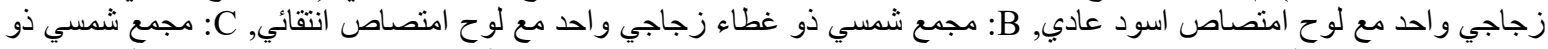

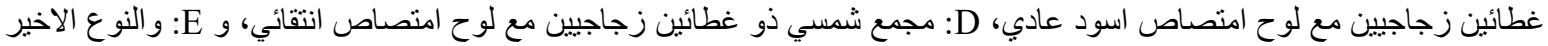

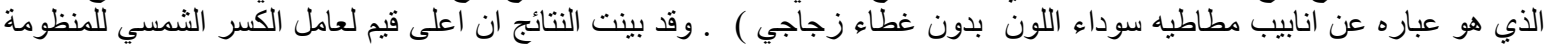

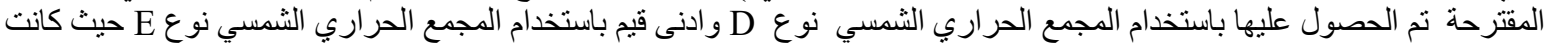

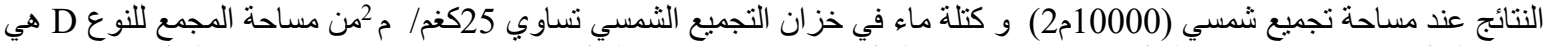

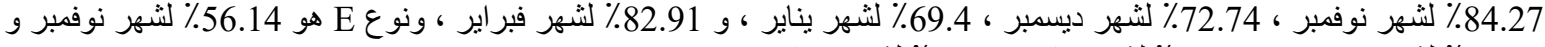

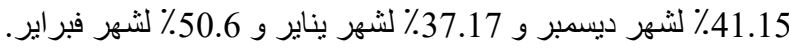

الكلمات الرئيسية ـ " منظومة تدفئة شمسيه", "مساحة التجميع الثمسي", "نوع المجمع الثمسي, "حمام سباحة داخلي", "معامل الكسر الثمسي ". 